Kotzab, Herbert, Teller, Christoph. 2005. Development and Empirical Test of a Grocery Retail Instore Logistics Model. British Food Journal, 107 (8), pp. 594-605.

\title{
DEVELOPMENT AND EMPIRICAL TEST OF A GROCERY RETAIL INSTORE LOGISTICS MODEL
}

Herbert Kotzab ${ }^{1}$, Christoph Teller ${ }^{2}$

1 - Department of Operations Management, Copenhagen Business School, Frederiksberg, DK 2000,

$$
\text { Denmark }
$$

Email: hk.om@cbs.dk - corresponding author

2 - Department for Retailing and Marketing, Vienna University of Economics and Business Administration, Vienna, A-1090, Austria

Email: christoph.teller@wu-wien.ac.at

Paper Type: Research Paper

WE THANK THE ANONYMOUS REVIEWERS FOR THEIR VALUABLE COMMENTS THAT HELPED TO IMPROVE THE PAPER. 


\title{
DEVELOPMENT AND EMPIRICAL TEST OF A GROCERY RETAIL INSTORE LOGISTICS MODEL
}

\begin{abstract}
The purpose of the paper is to introduce a model of Instore Logistics for retail stores. The model attempted to give a picture of all logistics processes that are carried out within a retail outlet from an incoming dock the check out model has afterwards been empirically validated by analyzing the Instore Logistics processes of dairy products in 200 stores in the Austrian grocery retail sector. The findings of the survey show typical problem areas within store operations and identify the impact of the final 50 metres in the store as a key factor impacting upon the success of retail business. The paper continues the work of Raman, DeHoratius \& Ton (2001) and Cachon (2001) and the findings contribute to close the execution gap in retail operations.
\end{abstract}

\section{Keywords:}

Supply Chain, Logistics, Retail operations, Instore Logistics, Dairy products

\section{INTRODUCTION}

We try in our paper to look at logistics activities that occur within a retail store. We call this phenomenon 'Instore Logistics' and consider it as a part of retail logistics that has become an important issue for practitioners and researchers especially when focusing on the 'last mile' problem within an E-commerce context (Kopczak, 2001). Our suggestion of 'Instore Logistics' is a 'hot topic' due to the dominance of store-based retailing (Levy \& Weitz, 2004). The analysis of the flow of goods within a self service retail outlet from a supply chain perspective can be of two reasons quite 'appealing' (Liebmann \& Zentes, 2001):

a) The availability of products in the shelves is an important key performance indicator for the purchasing transaction; 
b) Inventory carrying and handling costs as well as costs for human resources are at that level of a supply chain relatively intense.

Nevertheless, Pal \& Byrom (2003) recognize the variables 'stock in the outlet', 'space' (= the size of the sales area of a store), 'system' (= replenishment operations), 'standards' (of service, e. g. shelf availability, special order facilities, opening hours) and 'staff' as essential drivers for the shoppers' benefit. Raman, DeHoratius \& Ton (2001) have proven in two cases that operational mediocrity is due to a lack of knowledge on the real availability in the store and out-of-stock-situations at the point of sale (POS). The industrial initiative of Efficient Consumer Response Europe (ECRE) presented in 2003 additional sources for poor excellence in a retail outlet such as erroneous order management by store managers and deficient shelf filling activities (ECRE, 2003). We summarize the existing discussion as the combination of certain production factors such as staff, store size, assortment, etc. that explain the existence of different types of retail store, lead to specific outputs that might be sub-optimal measured in non-availability of products (= out of stock). These issues are also of importance as the majority of retailers operate with very low margins (Cachon, 2001; Theis, 1999). Though the consequences are evident, it seems that the academic and practical discussion avoids the discussion of operational issues within a retail store, such as Instore Logistics, which we consider as a 'black-box'understanding of retail operations. This is therefore surprising as Raman, DeHoratius \& Ton (2001) recognized 'execution' as the missing link in retail operations.

We further develop this idea by proposing a model of Instore Logistics as an additional piece of retail operations on a store level. The purpose of our paper is twofold. First we are going to develop a generic model of Instore Logistics consisting of specific product flow processes that can be applied in any store format. We have then in a second step empirically validated our model suggestion based on 202 face-to-face interviews with store managers representing different store types of a leading retail chain within the Austrian grocery industry. There we looked at the flow activities related with a specific product category (= dairy products). The analysis will show that our model can be used to analyze Instore logistics' specific flow activities independent from the store format. 


\section{SUPPLY CHAIN MANAGEMENT IN A RETAILING CONTEXT}

A supply chain is defined as the sum of ,... all activities associated with the flow and transformation of goods from raw materials stage (extraction), through the end user, as well as the associated information flows" (Handfield \& Nichols, 1999). The scope of a supply chain is to "span the entire set of organizations from procurement of material and product components to delivery of the completed product for the final customer" (Schary \& Skjøtt-Larsen, 1995). Both definitions include the existence of intermediaries in a supply chain in order to fulfil the ultimate goal of supply chain management - integration of business processes in order to satisfy end user satisfaction (Cooper, Lambert \& Pagh, 1997). Intermediaries such as retailers represent today more than $10 \%$ of GDP (US: $15.1 \%$, GB: $11.7 \%$, Germany: $10.4 \%$ of GDP). Retailing companies belong to the most important employers (US: 23.6\%; GB: 17.1\%; Germany: $15.1 \%$ of total employment) in many leading economies (Fisher \& Raman 2001; OECD, 2004). Today's retailers have to perform on an extra-ordinary level by combining different decisions regarding location, assortment, selection of target markets, negotiations with suppliers, motivation of staff and other typical marketing mix decisions, such as pricing and merchandising and all is done in a very competitive and global environment (Levy \& Weitz, 2004; Fernie, 1992; Fernie, 1999 or Azuma \& Fernie, 2001). Since the 1990's we could observe an increasing importance of retail logistics, which was recognized to generate competitive advantages by increasing product availability at lower costs (e.g. Paché 1998; Fernie 2000; Bourlakis \& Bourlakis, 2001 or Gudehus \& Brandes, 1997). Sparks (1999) also points out that logistics and Supply Chain Management (SCM) can be seen as important retail activities since they are very much concerned with product availability. And supply chain operations play a more and more significant role in a practical retailing context (e.g. Fernie al., 2000; Sparks, 1999 or Paché, 1998). Poor execution of logistics at the retail outlet level can lead to unsatisfying results as Raman, DeHoratius \& Ton (2001), Fisher \& Raman (2001) or Cachon (2001) have shown.

Fearne \& Hughes (1999) have demonstrated how supply strategies improve the competitiveness of British fresh food industry. Especially the upcoming of vertical partnerships between retailers and manufacturers in form of superior logistics strategies 
such as ECR or category management are suggested as success factors for the industry (e.g. Fearne, 1998 or Fearne \& Hughes, 2000). But we made out a research deficit when it comes to the analysis of logistics processes that occur in the retail outlets.

\section{DEVELOPING A MODEL OF GROCERY RETAIL INSTORE LOGISTICS}

Instore Logistics focuses on all flow processes within outlets of store-based retailing. The outlet itself represents a transition/exchange location as products are exchanged against payment. Therefore availability plays a major role for such retailing activities as no product available means no purchasing transaction.

The outlet as a logistical point of destination is clearly determined with the spatial borders of the store. Our concept of Instore Logistics does not recognize the flow of goods and information to the outlet and from the outlet. Instore Logistics' central objects are the products as purchased by end users (= primary packaging, end user packaging units) and relevant information (e.g. order information). Consumers as logistical objects are not included in our notions. Based on these assumptions we characterize Instore Logistics as presented in Table 1. 
Table 1 - Characterisation of Instore Logistics (adapted from Toporowski, 1996; Kotzab, 2000; Schnedlitz \& Teller, 1999)

\begin{tabular}{|l|l|}
\hline Point of Destination & Point of Sale - shelves \\
\hline Point of delivery & Incoming dock of the retail outlet \\
\hline Objects & Single Stock keeping units and related information \\
\hline Tasks & $\begin{array}{l}\text { Transportation } \\
\text { Inventory carrying and shelf management } \\
\text { Handling, Picking/Packing } \\
\text { Labelling } \\
\text { Order management/replenishment }\end{array}$ \\
\hline
\end{tabular}

The ultimate goal of Instore Logistics is efficiency, which means to offer the quantities of items as requested by end users at lowest costs possible.

As self-service has gained major importance in many fields of retailing, we concentrate our notions on Instore Logistics in self-service grocery outlets. There, the particularities for Instore Logistics can be seen in logistical frictions between staff and end users as consumers fulfil certain logistical activities within a store. The trigger for replenishment processes is initiated either by store employees or automatically by retail merchandise information systems. We perceive Instore Logistics like any other logistics system consisting of specific subsystems (=processes), which we tried to conceptualize as outlined in Figure 1. 


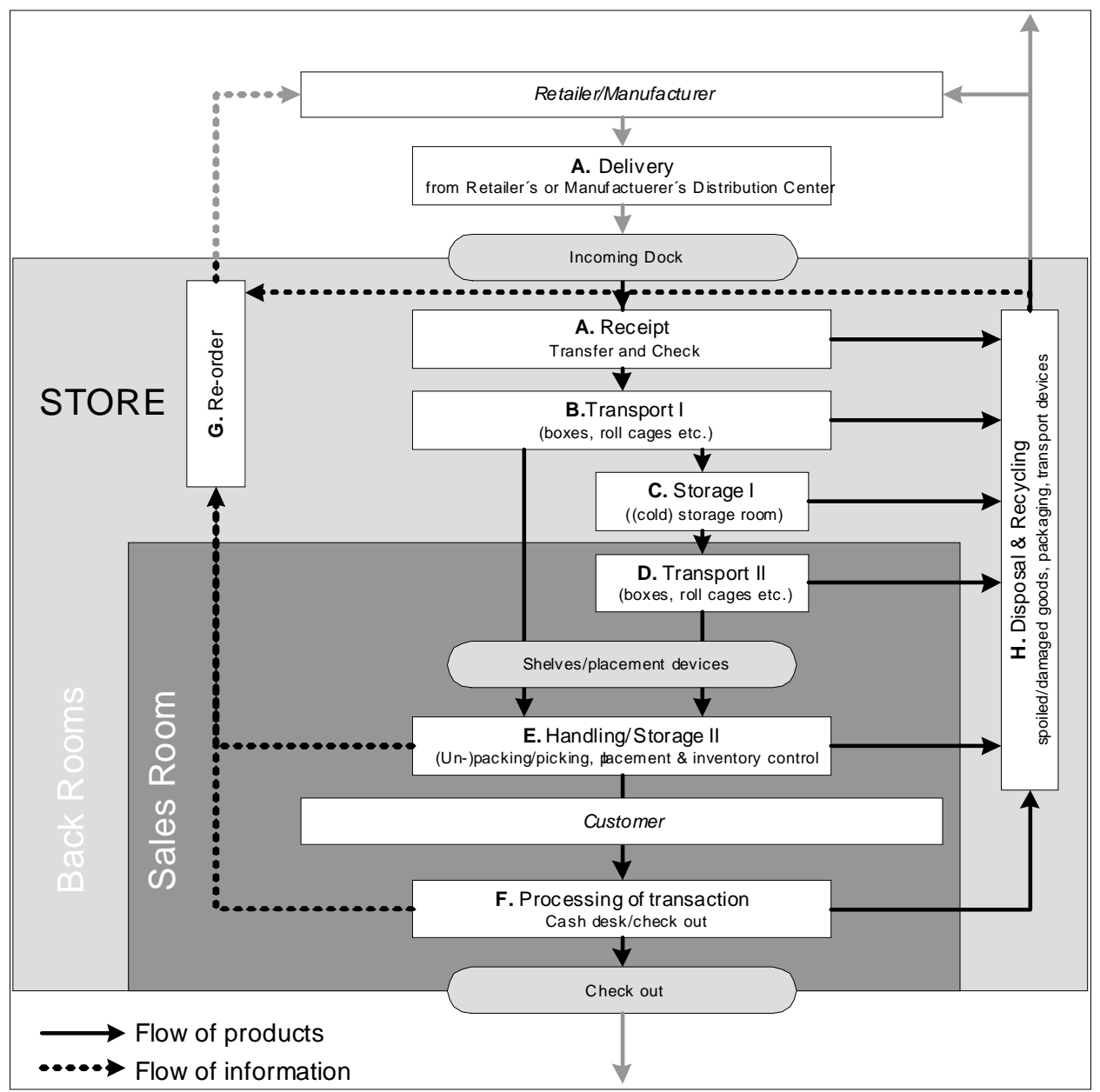

Figure 1: Instore Logistics processes

We consciously build our model on a generic level in order to apply it in heterogeneous store format settings. In addition we focused first on physical flows of products and not so much on the related information. We believe that Information Technology (IT)-Systems such as EPOS connections with Material or Distribution Resource Planning systems (MRP/DRP) or the applications of Radiofrequency Identification (RFID) can be seen as a fundamental element of our model.

Our presentations follow the typical systems thinking and sequential process linking in logistics:

- Delivery/Receipt: Products are delivered either from a retailer's distribution centre (DC) or from a DC of a logistics service provider/vendor to the receiving area of a store. Store employees take over and control the delivery. 
- Transport I: Incoming goods are either transported directly to the shelves (storage II) or to a specific temporary storage area (storage I).

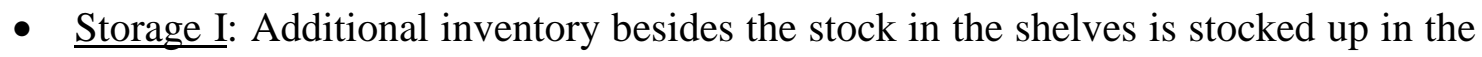
back store area. Tertiary packaging (= roll container/cages, pallets) is broken up to smaller units.

- $\quad$ Transport II: This transport activity refers to the transport from the back store area to the shelves.

- Handling/Storage II: This stage refers to all activities that are needed to prepare shelve filling such as break bulk of transportation units to end user units, shelve filling and merchandise presentation. This process includes also inventory control in order to generate re-ordering and replenishment.

- Processing of transaction: These activities refer to the exchange processes when end-users finally pay for their purchase. The dispatch of the products leads to replenishment activities and should ideally lead to automated re-ordering.

- Re-order: By controlling permanently all flows of products (incoming/outgoing) and the inventory management, orders might go to a headquarter or to a vendor.

- Disposal/Recycling: This includes either the removal of packaging material or the recycling of damaged/broken merchandise. It also generates information for order management. This step as well contains the re-channelling of packaging and transportation units.

All these processes are depending on (stochastic) end user demand and the replenishment processes of the preceding echelons of the supply chain. We can also determine other influencing factors such as the characteristics of the logistics objects (e.g. weight, size, quantity, value, perishableness, etc.), logistical dimensions (e.g. spatial and timely differences), as well as logistical relevant determination factors of retail stores (e.g. location).

In order to validate our assumptions, we tested our model in a specific real life setting. We assumed thereby differences of Grocery Instore Logistics processes for a specific product within different types of retail stores. 


\section{PRESENTATION AND DISCUSSION OF SELECTED RESULTS OF THE EMPIRICAL STUDY - THE CASE OF AUSTRIAN DAIRY PRODUCTS}

\section{$\underline{\text { Research design and Execution }}$}

We have chosen a face-to-face-interview approach with store managers of grocery retail outlets in order to validate our assumptions. We have interviewed 202 store managers of a leading grocery chain, representing three store types (following the typology of ACNielsen 2004a) - 147 supermarkets (size between 400 to 1000 sqm), 36 small hypermarkets (size between 1000 to 2999 sqm) and 19 large hypermarkets (size over 3000 sqm). Our sample includes all stores of the chain within the capital city of the home market, i. e. Vienna. We confronted the respondents with our generic model as presented in the previous sections of this paper. Therefore the chronology of the questionnaire includes 65 questions (open/closed; metric and ordinal scale level) following the sequence of Instore Logistics processes.

We have chosen a grocery setting as self-service outlets with large assortments, high turnover are the dominating store types in grocery retailing. We tested our notions of 'Grocery Retail Instore Logistics' within the product line of dairy products, which is according to Raman, DeHoratius \& Ton (2001) “an example of such a low-price but highstock-out cost item" with specific logistical requirements such as temperature, pressure, perishableness and high turnover.

This category includes according to ACNielsen (2004b) the following items: the white pallet (e.g. freshmilk, whole milk, curd cheese, yogurt and cream), the coloured pallet (e.g. fruit yogurt, curdled milk with fruit, milk mix drinks, fresh desserts), the yellow pallet (hard cheese, cut cheese, soft cheese or cream cheese) and the yellow fat pallet (e.g. butter, margarine or butter oil). The sales volume of this category totalled nearly EUR 1.3 billion and represents about $11.3 \%$ of the Austrian grocery retail sales volume. Dairy products also belong to the product category with a short consumption cycle and therefore create 
customer frequency in stores which makes them extremely interesting for store managers in grocery retailing. The interview consisted of three parts: a) assessment of the logistical distance indicators of time and space in order to characterize the input/output relation of Instore Logistics; b) evaluation of the usages of the Instore Logistics execution and c) the identification of the process specific differences between store formats.

\section{Discussion of selected results}

\section{Basic conditions regarding Instore-Logistics}

Table 2 summarizes the logistical relations and structural differences of the examined store types. Those variables turn out to be statistically significant different between all three store formats (Mann-Whitney U-test, $\mathrm{p}<0.05$ ) approving the heterogeneity between the three formats. The high values for the standard deviation within the category of supermarkets refer to a low standardization degree due to inner-city locations with specific physical structure. This means specific requirements for Instore Logistics as the width of the outlets and the placement of the products within the store vary a lot.

Table 2-Instore Logistics' key data of the observed store formats

\begin{tabular}{|c|c|c|c|c|c|c|c|c|c|}
\hline & $\mathrm{M}$ & SD & $\mathrm{n}$ & M & SD & $\mathrm{n}$ & M & $\mathrm{S}$ & $\mathrm{n}$ \\
\hline Store format & \multicolumn{3}{|c|}{ Supermarket } & \multicolumn{3}{|c|}{$\begin{array}{c}\text { Small } \\
\text { Hypermarket }\end{array}$} & \multicolumn{3}{|c|}{ Large Hypermarket } \\
\hline Space Store (sqm) & 685.9 & 240.4 & 122 & 1876.8 & 639 & 28 & 5010 & 1470 & 12 \\
\hline $\begin{array}{l}\text { Space Sales Room } \\
\text { (sqm) }\end{array}$ & 504.4 & 143.8 & 139 & 1419.4 & 398.1 & 32 & 4303.4 & 1040.8 & 16 \\
\hline $\begin{array}{l}\text { Number of employees } \\
\text { (full \& part time) }\end{array}$ & 18.1 & 18.4 & 143 & 32.4 & 14.8 & 30 & 60.8 & 25.9 & 6 \\
\hline $\begin{array}{l}\text { Length of the shelves } \\
\text { (fridge }(\mathrm{m})\end{array}$ & 10.2 & 11.6 & 120 & 15.7 & 4.6 & 36 & 34.8 & 16.1 & 19 \\
\hline $\begin{array}{l}\text { Number of stock } \\
\text { keeping units }\end{array}$ & 309.5 & 224.3 & 105 & 412.9 & 182.7 & 24 & 757.4 & 417.1 & 10 \\
\hline
\end{tabular}

We will refer in the next sections only to statistically significant differences between the types of stores. 


\section{Characterization and analyses of Instore-Logistics Processes}

\section{Delivery/Receipt}

In all the examined outlets dairy products were received on a daily basis. The delivery time was mainly outside the regular shopping hours $\left(58.9 \%, \mathrm{n}^{*}=\right.$ valid answers $\left.=190\right)$. In $46 \%$ of the cases $(n=202)$, dairy products were delivered with other fresh products. $95 \%$ of the products were delivered in a cooled manner $(n=202)$ and $92.5 \%(n=202)$ of all respondents indicated that the delivery of dairy products did not affect the other Instore Logistics processes. In $33.2 \%$ of the stores $(n=201)$, store employees were present while the products were delivered. Only in a few cases $(11.4 \% ; n=202)$, retail personnel brought the products from the truck into the outlet. The majority of the deliveries was cross checked with the order form $(61.5 \% ; n=200)$ and the delivery note $(76.2 \% ; n=202)$. This control step took 24.7 minutes (SD (=standard deviation): $24.6 ; \mathrm{n}=187$ ) and we could not identify any statistical significant differences between the store types. Also the number of products did not affect the duration of the control process (correlation-analysis, $\mathrm{p}=0.3$ ). In terms of problem areas at this stage of Instore Logistics, our respondents indicated differences between the promised delivery date and the actual delivery date. This difference was in three quarters of the cases $\left(3^{\text {rd }}\right.$ quartile; $\left.n=53\right)$ up to 120 minutes. The overall satisfaction with the delivery intervals $(97.5 \% ; n=201)$ and delivery date $(88.1 \% ; n=201)$ can be considered as relatively high.

The respondents estimated the share of damaged products to be lower than 3\% (M (mean): 2.9; SD: 4.7; $\mathrm{n}=187)$. Damaged goods were claimed in $40 \%$ of the cases at the retail headquarter, $36 \%$ was written off and/or was recycled in 59\% of all cases (multiple responses: 287). The overall satisfaction with the tertiary packaging (= roll container) was average (5 point Likert Scale; M: 3; SD: 1; $\mathrm{n}=201$ ). Store managers of large hypermarkets were significantly less satisfied than store managers of supermarkets (Mann-Whitney-UTest; $\mathrm{p}<0.05$ ), which could be due to the number of SKU's to be handled in the larger store formats.

\footnotetext{
* Not all respondents were capable and/or willing to answer questions in an appropriate way. This is the reason why ' $n$ ', i. e. valid answers, vary throughout the presentation of empirical results.
} 
In general it can be said that our respondents perceived the preliminary Instore Logistics process as working in a proper way. However in some cases the employees could not rely on accurate delivery of goods, which makes manpower planning challenging.

\section{Storage I}

All outlets had a cold room besides cooling devices. The average size of the cold rooms was 13.9 sqm (SD: $9.7 ; n=197$ ). The store managers considered the size of the cold room as satisfactory $(95 \% ; \mathrm{n}=200)$. In case of shortage, store managers mainly used an alternative cold room $(n=56)$. We also asked about the duration of storage of selected dairy products representing fast movers such as fresh, butter and curdled milk, plain yoghurt, whipped and sour cream and curd. The average storage time over all those products was 12.5 hours (SD: 13; $\mathrm{n}=196)$. The longest duration time was identified in the small hypermarkets, which was significantly higher than in the other store formats (see Table 3 ). This could be due to the different shopping frequency of the consumers. One typical problem the respondents perceived was the expiry date. Based on these results we can conclude that the storage I process is well dimensioned although we could make out certain indications for over capacities. These findings have to be limited to the specific time the interviews were conducted, i. e. June and Mai. At this time the demand for groceries or diary products was not extraordinary high compared to time periods before holidays and/or weekends. It seems to be clear that storage capacities have to be dimensioned according to the peak demands which explains our findings.

\section{Transport I \& II}

Here we measured the specific length of the distances within the stores. The spatial difference between the receiving area and storage I was on average 24.6 metres (SD: 54.8; $\mathrm{n}=194$ ). The distance between storage I and the cooling shelves (devices) was on average 29.1 metres (SD: 54.3; $\mathrm{n}=199$; see also Table 3). 
Table 3- Instore Logistics key data of observed store formats

\begin{tabular}{|c|c|c|c|c|c|c|c|c|c|}
\hline & $\mathrm{M}$ & SD & $\mathrm{n}$ & $\mathrm{M}$ & SD & $\mathrm{n}$ & $\mathrm{M}$ & SD & $\mathrm{n}$ \\
\hline Store format & \multicolumn{3}{|c|}{ Supermarket } & \multicolumn{3}{|c|}{$\begin{array}{l}\text { Small } \\
\text { ypermarket }\end{array}$} & \multicolumn{3}{|c|}{$\begin{array}{c}\text { Big } \\
\text { Hypermarket }\end{array}$} \\
\hline Storage space (sqm) & $11.3^{\mathrm{A}, \mathrm{B}}$ & 5.9 & 144 & $17.4^{\mathrm{A}, \mathrm{C}}$ & 10.3 & 34 & $27^{\mathrm{B}, \mathrm{C}}$ & 17.6 & 19 \\
\hline $\begin{array}{l}\text { Storage time (hours) of } \\
\text { selected dairy products } \\
\text { (M) }\end{array}$ & $10.9^{\mathrm{A}}$ & 11.2 & 144 & $20.4^{\mathrm{A}, \mathrm{C}}$ & 17.6 & 34 & $10.2^{C}$ & 12.1 & 18 \\
\hline $\begin{array}{l}\text { Spatial Distance: } \\
\text { Incoming Dock - cooling } \\
\text { chamber }\end{array}$ & 21.8 & 37.4 & 142 & 39.3 & 107.1 & 33 & 20.7 & 18.5 & 19 \\
\hline $\begin{array}{l}\text { Spatial Distance: Cooling } \\
\text { chamber - shelves }\end{array}$ & $22,9^{A}$ & 37.7 & 146 & $50.9^{\mathrm{A}}$ & 95.7 & 35 & 37.5 & 50.4 & 18 \\
\hline $\begin{array}{l}\text { Spatial Distance: } \\
\text { Incoming Dock - Shelves }\end{array}$ & $33,7^{\mathrm{A}, \mathrm{B}}$ & 43.7 & 145 & $87.9^{\mathrm{A}}$ & 178 & 32 & $60.2^{\mathrm{B}}$ & 68,3 & 18 \\
\hline $\begin{array}{l}\text { Time for shelf } \\
\text { replenishment (h/day) }\end{array}$ & $2.7^{\mathrm{A}, \mathrm{B}}$ & 2.2 & 146 & $4.7^{\mathrm{A}}$ & 2.5 & 34 & $6.4^{\mathrm{B}}$ & 4.7 & 19 \\
\hline $\begin{array}{l}\text { Personnel needed for } \\
\text { shelf replenishment } \\
\text { (h/day) }\end{array}$ & $4.1^{\mathrm{A}, \mathrm{B}}$ & 3.7 & 144 & $8.8^{\mathrm{A}, \mathrm{C}}$ & 6.8 & 34 & $14.3^{\mathrm{B}, \mathrm{C}}$ & 10.4 & 19 \\
\hline Disposal (\% quantity/day) & 1.2 & 3.6 & 130 & 1.5 & 2.5 & 31 & 0.7 & 0.9 & 17 \\
\hline Disposal (\% value/day) & 1.3 & 4.2 & 118 & 1 & 2 & 26 & 1.1 & 1.7 & 15 \\
\hline Orders per week & $5.9^{\mathrm{B}}$ & 0.4 & 147 & 5,8 & 0,4 & 36 & $5,6^{\mathrm{B}}$ & 1 & 19 \\
\hline Time for order processing & $31.6^{\mathrm{A}, \mathrm{B}}$ & 16.3 & 147 & $48^{\mathrm{A}}$ & 31.1 & 36 & $71^{\mathrm{B}}$ & 46.5 & 19 \\
\hline
\end{tabular}

This was also due for the direct distance between delivery area and cooling shelves (M: 45 metres; SD: $85.5 ; n=195)$. In more than $50 \%$ of the outlets $(55.9 \% ; n=200)$ we could not identify any problems that might affect internal transportation. In all the other outlets it is the physical structure of the store that could be seen as the main transportation barriers (i.e. steps, doors, floor conditions, etc.).

\section{Handling/Storage II}

This process refers to the break bulk of transportation units to consumer specific units and handling in the shelves. This activity took on average 3.3 hours/day (SD: 2.9; n=199) and ties a lot of man-hours. On average, our respondents indicate 5.9 employee hours for this 
process (SD: 6.2; $\mathrm{n}=197$ ). Here we could also make out some differences between the store types as the number of articles in the dairy assortment varies. We also asked about the frequency of stock-outs regarding the selected products stated in process 'storage I'. The average value over all products was 4.6 meaning that there are almost never out of stock situations from the respondent's point of view (on a 5 point Likert Scale where 1= occurs very frequently; 5=never occurs). This corresponds also with our findings regarding overcapacities in the stores.

\section{Disposal}

In terms of disposal of dairy products, we asked for the share of removed articles based on the overdrawn expiration date. The average rate for disposals was calculated with an average of $1.2 \%$ of all articles (SD: $3.2 ; n=178$ ). From our selected dairy products, whipped cream (159), plain yoghurt (150) and sour cream (120) were most affected by damages. Looking at the root cause of these damages we identified the aluminium lid of the beaker $(n=138)$ or the beaker itself $(n=37)$, that were the weak points of the products causing disposal or reductions in price. Fresh milk $(n=89)$ and whipped cream $(n=79)$ were the products, which have been disposed most frequently. The reason for that high disposal rate was the comparable short expiry dates and damages. According to these results it can be said that disposal had been an indicator and a result of suboptimal logistics performance including inaccurate sales forecasts or bad delivery quality.

\section{Ordering}

Store Managers indicated to order products of this category on a daily basis (M: 5.9 times per week). We found out that dairy products in larger hypermarkets were not that frequently ordered, which might be due to larger inventory sizes in such stores. The order process took on average 38.2 minutes (SD: 26.6; $n=202$ ) and was shorter in supermarkets than in hypermarkets. The reason for that might have been the breath of assortment (\# of articles). In $29 \%$ of the cases, store managers did not order as suggested by the headquarter, and used those suggestions only in $12.9 \%$ of the cases. 
The results showed that employees only relied on automated re-ordering systems to a certain degree or being unburdened by IT to a minimum. The lack of knowledge regarding the demand and the inaccuracy of virtual and real stock in the stores could be a reason for that.

\section{Overall evaluation}

We have demonstrated with our description model that supply chain and operations processes on a retail store level are more complex and important than many researchers and practitioners believe. We found out that the main problem areas in our case were the following:

- Lack of knowledge on cost and service levels of day-to-day work such as showing of a carton;

- Lack of standardized optimization guidelines for all stores;

- Lack of qualified personnel; constructional defects and

- Lack of inappropriate architecture and store design.

In addition we saw that logistics activities disturb consumers' shopping experience, which all result in out-of-stock-situations due to lacking coordination of order management and replenishment at store/shelve level.

\section{CONCLUSIONS \& MANAGERIAL CONSEQUENCES}

Our approach showed that the fundamental goal of making products available for consumers can be split up into certain sub logistics processes, which on the one hand follow the logic of any logistics system, but on the other hand deal with very small units.

Our empirical results validated our assumptions and following consequences should be highlighted: 
- We made out two weak points, which are due to previous steps in the supply chain: a) deliveries behind time and b) damaged products. However, both cause negative consequences for managing staff and orders on a store level.

- Instore Logistics is a service and therefore dependent on trained personnel, especially in a self-service setting. IT can assist but is difficult to replace staff by IT for this process. It will be interesting to see in the future how the RFIDapplication could help in this area (see e.g. Metro 2004).

Based on our findings we identified also some dilemmas that occur, when taking a total chain view into account, as some improvements on the store level can lead to problems further up the channel:

- The delivery of pre-sorted units could save both parties' time and costs as merchandise can be delivered in store-specific logically sorted roll cages (=roll cage sequencing). However, this can lead to a shift of enormous and costly set up activities to distribution centres. Although roll cage sequencing (e.g. EAN-Austria 1997) can then improve the receipt activities at the store level because checking and replenishment can be done more efficient as the roll cages can be moved directly to the place where the merchandise is needed, from a DC-perspective this can lead to inefficiencies as full truck load principles and standardized routines can be interrupted.

- The replenishment of the shelves sometimes disturbs consumers' shopping activities. Therefore inventory can be placed directly behind the shelves, which in the case of dairy products is already done. Another possibility can be seen in replenishing the shelves after regular shopping hours by specific service providers (Büttgen, 2003).

In order to obtain these improvements, retail management is asked to measure the efficiency of their existing Instore Logistics systems, where our model can be used as a pragmatic tool in order to identify potential problem areas.

Limitations of our approach refer to the external validity of our results that has to be considered as limited, as we investigated our research phenomenon in one selected product area in the stores of one (leading) retail company. Due to specific characteristics of 
observed logistical objects (perishableness, sensitiveness to temperature, pressure, high shelf turnover etc.) other problems stemming from the high value of products were not being considered, such as shrinkage, theft, fraud etc. (Van Ossel, 2003) Alkohol (?) The results of our research can therefore not be drawn to all products of the examined types of stores.

The choice of our research approach also showed some weaknesses as the face-to-face interview was partly suitable regarding two issues. We found out that store managers were sometimes assisted by staff, which is mainly involved in Instore Logistics issues. Also when asking about out-of-stock-situations we identified some problems that can be avoided by measuring out-of-stock by observations. Though we have to point out that the most critical issue here is still the buying behaviour of the consumers. An alternative, although more expensive, might have been the observation combined with to the interview approach. Observations could also show certain specific activities that cannot be tested by interviews. We suggest considering adaptations of our approach in the future.

Our approach can also be considered to be on an exploratory level. Future research may include an expansion of our flow model with a more specific investigation of information (automated order processing, IT) and backward flows (Recycling, disposal). Another future research area refers to a simulation of different Instore Logistics processes based on our empirical data. It would be interesting to see how the influence of different parameters such as storage space, delivery times, share of damage goods etc. affects the availability of products. Such simulation can analyse which variables are really responsible for shelf availability of products within the Instore logistics system and give managers more insight into this neuralgic business area.

\section{ENGLISCHE ÜBERSETZUNG DER DEUTSCHEN TITEL!}

ACNielsen (2004a), "Statistical Yearbook 2004", Available http://www.acnielsen.at ACNielsen (2004b), "Dairy products definition”, internal presentation 
Azuma, X. and Fernie, X. (2001)

Büttgen (2003), "Sie verkaufen, wir sorgen für volle Regale“. [You sell, we ensure full shelves], http:www.teamwork-germany.com/regalservice/index.html

Cashon, G. (2001), "Managing a Retailer`s Space, Inventory, and Transportation", Manufacturing \& Service Operations Management, Vol 3 No 3, pp. 211-299

Cooper, M. C., Lambert, D. M. and Pagh, J. D. (1997), "Supply Chain Management: More Than a New Name for Logistics”, International Journal of Logistics Management, Vol 8, No 1, pp. 1-13

EAN-Austria (1997), ECR Handbuch Österreich I [ECR Handbook Austria], EAN-Austria, Vienna

ECRE (2003), “Optimal Shelf Availibility”. Available http://www.ecrnet.org/ conference/docs/Break-outs\%2014May2003/Optimal\%20Shelf\%20Availability/1Intro\%20Rackebrandt\%20RBerger.ppt

Fernie, X. (1992)

Fernie, X. (1998)

Fernie, X. (1999)

Fernie, X. And Hughes, X. (1999)

Fernie, X. And Hughes, X. (2000)

Fernie, X. et al. (2000)

Fisher, M. and Raman A. (2001), "Introduction to Focused Issue: Retail Operations Management", Manufacturing \& Service Operations Management, Vol 3 No 3, pp. 189-190

Handfield, R. B. and Nichols E. J. (1999), Introduction to Supply Chain Management, Prentice Hall, Upper Saddle River, NJ 
Kopczak, L. (2001), "Designing supply chains for the 'click-and-mortar' economy", Supply Chain Management Review, Vol. 5 No 1, pp. 60-66

Kotzab, H. (2000), "Handelslogistik" [Retail Logistics]. In: Klaus, P. and Krieger, W. (Ed.): Gabler Lexikon Logistik, Gabler, Wiesbaden, pp. 181-187

Kotzab, H. and Schnedlitz, P. (ACHTUNG nicht im TEXT) (1999), "The Integration of Retailing to the General Concept of Supply Chain Management concept", Journal für Betriebswirtschaft, Vol 49 No 4, pp. 140-153

Levy, M. and Weitz, B. (2004), Retailing Management, McGraw Hill-Irwin, Boston

Liebmann, H.-P. and Zentes, J. (2001), Handelsmanagement [Retail Management], Vahlen, Munich

Metro (2004)

OECD (2004), Stan new database. Available http://www.oecd.org/home/

Paché, X. (1998)

Pal, J. W. and Byrom, J. W. (2003), “The Five Ss of Retail Operations: a Model and Tool for Improvement", International Journal of Retail \& Distribution Management, Vol 31 No 10, pp. 518-528.

Raman, A., DeHoratius, N. and Ton, Z. (2001), "Execution: The Missing Link in Retail Operations", California Management Review, Vol 43 No 3, pp. 136-152

Schary, P. B. and Skjott-Larsen, T. (1995), Managing the global supply chain, Copenhagen School Press, Copenhagen

Schnedlitz, P. and Teller, C. (1999), "Aktuelle Perspektiven der Handelslogistik“ [Recent perspectives in retail logistics], in Pfohl, H.-C. (Ed.), Logistikforschung. Entwicklungszüge und Gestaltungsansätze [Logistics Research. Developments and Trends], Erich-Schmidt-Verlag, Berlin, pp. 233-252.

Sparks, X. (1999) 
Theis, H.-J. (1999), Handels-Marketing. Analyse- und Planungskonzepte für den Einzelhandel [Retail-Management. Analysis and planning concepts for retailing], Deutscher Fachverlag, Frankfurt am Main

Toporowski, W. (1996), Logistik im Handel. Optimale Lagerstruktur und Bestellpolitik einer Filialunternehmung [Logistics in retailing - optimal stock and order policy of a retail chain], Physica, Heidelberg

Van Ossel, G. (2003), "Fraud and shrinkage - facts \& figures", http://www.realsoftware.be/NR/rdonlyres/esch7qv3of3ygqcki3vuip4ovj5cp7aoog3nufb tu4uxae2bwgdcl4xh7goszwimm2xlmn3qmt136b/shrinkagetheftrealsoftwareNLhandout $\cdot \mathrm{ppt}$ 